\title{
Virus-induced secondary bacterial infection: a concise review
}

\author{
This article was published in the following Dove Press journal: \\ Therapeutics and Clinical Risk Management \\ 24 August 2015 \\ Number of times this article has been viewed
}

\author{
Mohamed A Hendaus' \\ Fatima A Jomha ${ }^{2}$ \\ Ahmed H Alhammadi ${ }^{3}$ \\ 'Department of Pediatrics, Academic \\ General Pediatrics Division, Weill- \\ Cornell Medical College, Hamad \\ Medical Corporation, Doha, Qatar; \\ ${ }^{2}$ School of Pharmacy, Lebanese \\ International University, Khiara, \\ Lebanon; ${ }^{3}$ Department of Pediatrics, \\ Academic General Pediatrics Division, \\ Weill-Cornell Medical College, Hamad \\ Medical Corporation, Doha, Qatar
}

\begin{abstract}
Respiratory diseases are a very common source of morbidity and mortality among children. Health care providers often face a dilemma when encountering a febrile infant or child with respiratory tract infection. The reason expressed by many clinicians is the trouble to confirm whether the fever is caused by a virus or a bacterium. The aim of this review is to update the current evidence on the virus-induced bacterial infection. We present several clinical as well in vitro studies that support the correlation between virus and secondary bacterial infections. In addition, we discuss the pathophysiology and prevention modes of the virus-bacterium coexistence. A search of the PubMed and MEDLINE databases was carried out for published articles covering bacterial infections associated with respiratory viruses. This review should provide clinicians with a comprehensive idea of the range of bacterial and viral coinfections or secondary infections that could present with viral respiratory illness.
\end{abstract}

Keywords: bacteria, infection, risk, virus

\section{Introduction}

Viral respiratory tract infections (VRTIs) are very common in children and their presentations vary from simple colds to life-threatening infections. ${ }^{1-5}$ The detection of a respiratory virus does not necessarily infer that the child has only a viral infection, ${ }^{6}$ since outbreaks of VRTIs are being linked to increased incidence of bacterial coinfections. ${ }^{7}$ The human body is usually capable of eliminating respiratory viral infections with no sequelae; however, in some cases, viruses bypass the immune response of the airways, causing conceivable severe respiratory diseases. ${ }^{8}$ Robust mechanical and immunosuppressive processes protect the lungs against external infections, but a single respiratory tract infection might change immunity and pathology. ${ }^{9}$

Health care providers often face a dilemma when encountering a febrile infant or child with respiratory tract infection. The reason expressed by many clinicians is the challenge to confirm whether the fever is caused by a virus or bacterium. ${ }^{10}$ Acute otitis media (AOM) is a usual bacterial coinfection that occurs in $20 \%-60 \%$ of cases of VRTIs. ${ }^{11-14}$ In addition, almost $60 \%$ of children with VRTI have changes in the maxillary, ethmoidal, and frontal sinuses. ${ }^{11,12}$ Moreover, in the year 1918, it was estimated that 40-50 million individuals died from the influenza pandemic, many of which were due to secondary bacterial pneumonia with Streptococcus pneumoniae. ${ }^{15}$

\section{Search strategy and selection criteria}

A search of the PubMed database and Google was carried out, using different combinations of the following terms: virus, induced, bacteria, pathogenesis, prevention, vaccine, and children. In addition, we searched the references of the identified articles for additional articles. We then reviewed abstracts and titles and included studies that were 
relevant to the topic of interest. Finally, the search was limited to studies of disease in humans that were published in English and Spanish from 1918 to the end of 2014 (Figure 1).

\section{Airway epithelium}

The epithelium (Figure 2) is usually covered by a layer of mucus that functions as a boundary. ${ }^{16}$ Mucins, which are charged glycoproteins, are the main components of mucus. ${ }^{17,18}$ MUC5AC and MUC5B are the most common mucins in the human sputum, and they assist the innate immune system through their anti-inflammatory and antiviral properties. ${ }^{19,20}$ In addition, they facilitate trapping and clearance of viruses; however, overproduction of those mucins might have a paradoxical effect. ${ }^{18,19}$

The airway epithelium not only functions as a physical barrier but also recognizes microorganisms through pattern recognition receptors such as Toll-like receptors (TLRs), ${ }^{18}$ nucleotide-binding oligomerization domain (NOD)-like receptors (NLRs), and retinoic acid-inducible gene (RIG)like helicases. ${ }^{21,22}$

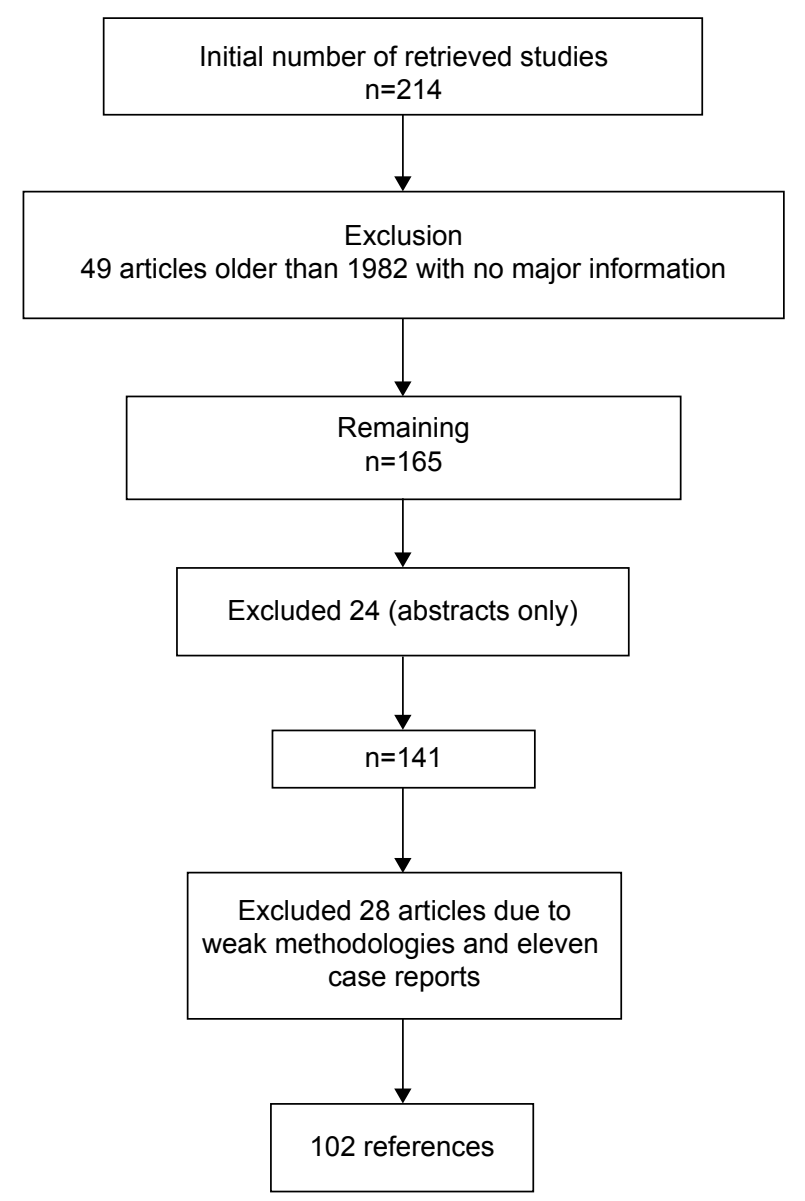

Figure I Flow diagram showing the selection of literature.
TLRs are single, noncatalytic, membrane-spanning receptor proteins used by the innate immune system. ${ }^{23}$ Respiratory viruses collaborate with TLR lanes, leading to extended bacterial load in the lungs..$^{21,24}$

In comparison, NLRs and RIG-like helicases activate innate immune responses through cytosolic sensing of viral and bacterial components. ${ }^{22,25}$ Nod1 and Nod2, which are family members of NLRs, are induced by molecules synthesized during the production and/or degradation of bacterial peptidoglycan. ${ }^{26-29}$ In addition, many epithelial cells express the classical antiviral interferons (INFs), especially IFN- $\alpha$ and IFN- $\beta \cdot{ }^{30,31}$ Moreover, the respiratory virus-infected epithelia facilitates the attraction of inflammatory cells, including natural killer cells, neutrophils, macrophages, and eosinophils from the bloodstream into the infected site. ${ }^{32}$ Finally, the airway epithelium consists of many molecules including intercellular adhesion molecule 1 (ICAM-1), carcinoembryonic antigen-related cellular adhesion 1 (CEACAM-1), and platelet-activating factor receptor (PAF-r). ${ }^{33}$ Viruses have an effect in modulating these receptors, leading to an increase risk of bacterial adherence; for example, rhinovirus upregulates the expression of PAF-r, leading to the binding of $S$. pneumoniae to bronchial epithelial cells. ${ }^{34}$

\section{Pathogenesis of superimposed secondary bacterial infection}

Different mechanisms might contribute to the debilitation in host defense of the respiratory tract against bacteria following viral infection. Some of the mechanisms have been extrapolated from studies conducted in animal models of sequential infections by respiratory viruses and several bacterial pathogens.

\section{Virus inflicts impairment on host epithelial cells}

Mammalian cells are prone to bacterial attachment during a viral illness. ${ }^{8,35}$ Viruses can debilitate the mucociliary clearance structure, leading to the increased attachment of bacteria to mucins and colonization; moreover, the condensed mucus will impede the penetration of antibacterial material and immune cells. ${ }^{36}$ Viruses like the respiratory syncytial virus (RSV) can damage ciliated cells, resulting in ciliostasis and, therefore, deterioration of mucociliary clearance. ${ }^{37}$ The same concept applies to an influenza virus infection, leading to decreased tracheal mucociliary velocity and clearance of $S$. pneumoniae. ${ }^{35,38}$ Moreover, virus-induced cell death debilitates the mechanical elimination of the 

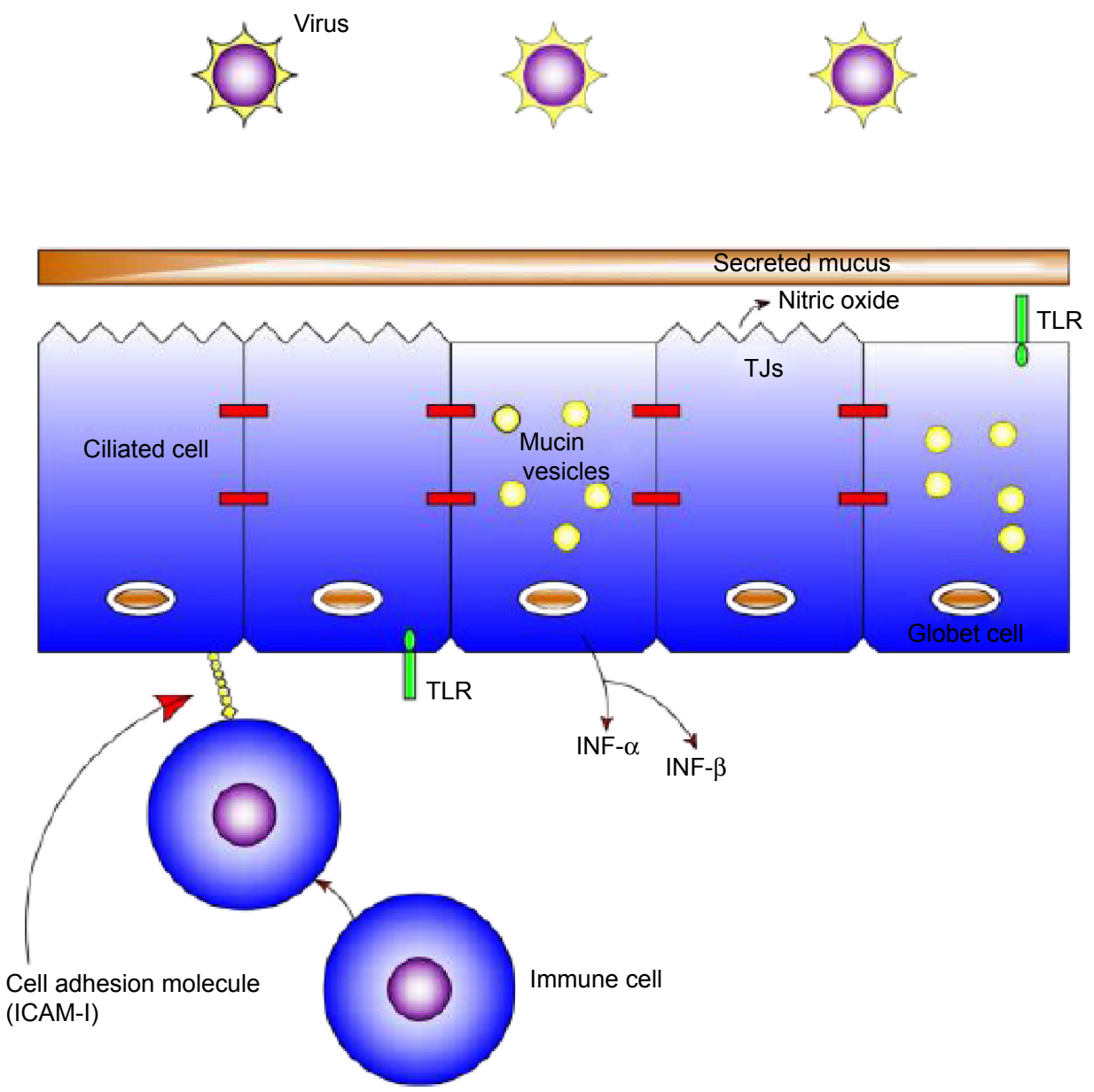

Figure 2 Airway epithelium.

Abbreviations: INF, interferon; TJ, tight junction; TLR, Toll-like receptor; ICAM-I, intercellular adhesion molecule I.

attached pathogens and displays novice receptors for bacterial adherence. ${ }^{39}$ Studies have shown that the RSV virus induces the adherence of S. pneumoniae, Pseudomonas aeruginosa, and Haemophilus influenza to airway epithelial cells. ${ }^{40-43} \mathrm{In}$ addition, adenovirus and rhinovirus play the same role in the adherence of S. pneumoniae to the airway epithelial cells; $;$, ${ }^{84}$ however, the measles virus decreases the risk of adherence of streptococcal bacteria, implying that every virus has a specific mode of changing the host cell membrane.$^{44}$ Moreover, bacterial adhesion might also be a result of the upregulation of surface receptors including PAF-r, which is involved in pneumococcal invasion. ${ }^{45,46}$

In patients with cystic fibrosis, bacterial adherence forms a biofilm, creating permanent airway colonization with $P$. aeruginosa.$^{47}$ Viruses such as RSV, rhinovirus, and influenza virus also lead to pneumococcal biofilm formation on the airway lining. ${ }^{48}$ Furthermore, RSV increases the risk of adherence of Staphylococcus aureus and Bordetella pertussis to Hep-2 (human epidermoid cancer) epithelial cells. ${ }^{49,50}$

\section{Virus effect on the immune system}

Post-viral sustained desensitization of lung sentinel cells to TLR signals may be one possible contributor to the common secondary bacterial pneumonia associated with viral infection. For instance, TLR4 and TLR5 pathways are altered after influenza virus infection, resulting in decreased neutrophil attraction, thereby leading to increased attachment of S. pneumonia and $P$. aeruginosa to the airway epithelial cells. ${ }^{25}$

The interrelation between host cells and microorganisms during an infection induces immune responses that include the generation of proinflammatory molecules. Despite their crucial role as a bactericidal, proinflammatory cytokines such as TNF- $\alpha$ produced in response to infection could be detrimental to the host cells..$^{51}$ During a viral infection, TLR and RIG-I-like receptor activation induces production of type I IFNs, which can augment the inflammatory response to TLR ligands including lipopolysaccharide (LPS). ${ }^{52,53}$ In addition, certain bacteria such as $S$. aureus integrate into the A549 respiratory epithelial cells (adeno-carcinomic 
human-alveolar basal-epithelial_cells) during a respiratory viral infection by increasing the expression of ICAM-1. ${ }^{54}$ RSV differs from influenza virus in that the former upregulates cellular receptors including CEACAM-1 and ICAM-1, which eventually leads to bacterial infection. ${ }^{45}$ Finally, interaction between type I IFNs and Nod1/Nod2 signaling leads to bacterial recognition, but indicts harmful effects in the virally infected host. ${ }^{55}$

\section{Clinical presentation}

Corollary and secondary bacterial infections in patients with viral diseases are known to coexist. A study conducted by O'Brien et $a^{56}$ showed that the influenza virus (H1N1) was the culprit of the severe pneumococcal pneumonia outbreak among children that occurred in Iowa in the mid-1990s. Other studies have shown that almost one-third of children with community acquired pneumonia (CAP) had mixed (viral and bacterial) infection. ${ }^{57,58}$ Moreover, a study in France showed that influenza virus infection was the direct cause of CAP in $12 \%$ of children. ${ }^{59}$ Syrjanen et $\mathrm{al}^{60}$ found in their study that the isolation of $S$. pneumonia from the nasopharyngeal area was higher during respiratory infection without concomitant AOM. Viral respiratory infection due to RSV, influenza virus (type A or B), and adenovirus increase the incidence of otitis media (OM) and recurrent $\mathrm{OM}$ in children. ${ }^{61,62}$ Ruuskanen et $\mathrm{al}^{63}$ found that there is a concrete association between AOM and $57 \%$ of children with RSV, 33\% with parainfluenza type 3 virus, 30\% with adenovirus, 35\% with influenza $\mathrm{A}$ virus, $28 \%$ with parainfluenza type 1 virus, $18 \%$ with influenza $B$ virus, and $10 \%$ with parainfluenza type 2 virus infections; the most common bacteria isolated from tympano-centesis were H. influenzae, S. pneumoniae, Branhamella catarrhalis, and Mycoplasma pneumonia. Another study showed that the rates of bacteremia and OM were $18 \%$ and $44 \%$, respectively, in children with viral-induced bronchiolitis. ${ }^{11}$ The highest incidence of AOM is usually 2-5 days after an upper respiratory infection. ${ }^{64,65}$ Isolation of viruses alone from sinus aspirates or in concomitance with bacteria proposes the role of viruses in the induction of bacterial sinusitis, ${ }^{62}$ with rhinovirus and parainfluenza viruses being the culprits. ${ }^{66}$ The rate of bacteremia in children with acute bronchiolitis ranges from $0.2 \%$ to $1.4 \% .{ }^{67-75}$ In addition, the rate of bacterial urinary tract infection (UTI) in children with bronchiolitis can be as high as $11.4 \%{ }^{67}$ In a recent study, Hendaus et al ${ }^{76}$ assessed the prevalence of UTI in infants and children with bronchiolitis. The study included 835 hospitalized children with acute bronchiolitis. The results disclosed that UTI was found in $13.4 \%$ with bronchiolitis triggered by a respiratory viruses such as rhinovirus $(31 \%)$, adenovirus $(14 \%)$, parainfluenza virus type $4(14 \%)$, bocavirus $(10 \%)$, human metapneumovirus (10\%), coronavirus $(7 \%)$, parainfluenza virus type $3(3.4 \%)$, parainfluenza virus type $2(3.4 \%)$, parainfluenza virus type 2 (3.4\%), and H1N1 (3.4\%). Rittichier et $\mathrm{al}^{77}$ have researched the effect of respiratory viruses on the risk of acquiring serious bacterial infection, including UTI. The study concluded that febrile infants with enterovirus had a coexisting rate of serious bacterial infection of $6.6 \%$.

\section{Role of myxovirus resistance protein I (MxA) in differentiating between viral and bacterial infections}

The human myxovirus resistance protein 1 (MxA) is an important intermediary of the IFN-induced antiviral response against a variety of viruses. MxA expression is firmly modified by type I and type III IFNs, which also requires signal transducer and activator of transcription 1 signaling. Additionally, MxA has many characteristics similar to the superfamily of large guanosine triphosphatases. ${ }^{78} \mathrm{MxA}$ analysis could be beneficial to differentiate between bacterial and viral infections. Engelmann et $\mathrm{al}^{79}$ conducted a prospective, multicenter cohort study in different pediatric emergency departments in France on the role of MxA in the diagnosis of viral infections. MxA blood values were calculated in infants and children with verified bacterial or viral infections, uninfected controls, and infections of unknown origin. A receiver operating characteristic analysis was used to verify the diagnostic performance of MxA. The study, which included 553 children, showed that MxA was significantly higher in children with viral versus bacterial infections and uninfected controls $(P<0.0001)$. Additionally, MxA levels were significantly higher in children with clinically diagnosed viral infections than in those with clinically diagnosed bacterial infections $(P<0.001) .{ }^{79}$ Other authors have also reported the usefulness of blood MxA testing in patients with viral infections. ${ }^{80,81}$ The use MxA in diagnosing viral infection is very promising, especially in patients who are at risk of infectious complications. Two separate studies have shown that blood MxA is beneficial in differentiating between viral illness and acute graft-versushost disease after allogenic stem cell transplantation..$^{82,83}$

\section{Prevention of secondary bacterial infection}

It has been recommended that treatment or prevention of a viral disease may be a superior method for diminishing 
of complications from influenza. ${ }^{84,85}$ Since viral infections might lead to secondary bacterial infection, it is prudent to vaccinate patients with the influenza vaccine to diminish the risk of $\mathrm{OM}$ in children and pneumonia in adults. ${ }^{62}$

It has also been published that live attenuated influenza vaccine is effective in reducing the incidence of all-cause $\mathrm{AOM}^{86-88}$ and pneumonia ${ }^{89}$ compared to placebo in children. In addition, the intranasal influenza vaccine can reduce OM by $44 \% .{ }^{90}$ Moreover, studies have shown that a combined influenza/pneumococcal vaccine is efficient in the prevention of OM in children and pneumonia. ${ }^{91,92}$ However, the credit of protection was awarded to the influenza vaccine since studies have shown that pneumococcal vaccine has no benefit in the reduction of AOM. ${ }^{93,94}$ In addition, the pneumococcal polysaccharide vaccine showed no efficacy in the prevention of pneumonia in adults. ${ }^{95}$

Treatment of viral infection is anticipated to prevent bacterial superinfections. Currently, the only respiratory virus that is pharmacologically treatable is the influenza viruses (Type A and B). ${ }^{62}$ Neuraminidase inhibitors can potentially diminish the morbidity related to influenza. ${ }^{96}$ Oseltamivir can reduce the incidence of AOM in preschool children, ${ }^{97}$ and the reduction rate can be up to $44 \% .^{98} \mathrm{~A}$ meta-analysis review showed that oral oseltamivir reduces the rate of hospitalization by $25 \%$ and morbidity by $75 \% .{ }^{99}$ In addition, its use can reduce the use of antibiotics by up to $50 \%,{ }^{100,101}$ The same concept of protection applies to vaccines that prevent against RSV infections. ${ }^{62}$ The vaccine available for RSV is palivizumab (MedImmune, Gaithersburg, MD, USA), a humanized monoclonal antibody that perceives the fusion protein of RSV. The other monoclonal antibody that is under clinical trials is motavizumab (MedImmune), which has a higher affinity for RSV fusion protein than palivizumab and can prevent against medically attended lower respiratory tract infection. ${ }^{102}$

\section{Conclusion}

The rate of concurrent serious bacterial infections with viral illness is appreciable. Similar emphasis must be given to the prevention and treatment of viral illnesses, especially in young children. Furthermore, health care providers should emphasize to parents on the importance of clinical follow-up of infants and young children diagnosed with VRTI. Moreover, the introduction of MxA in the diagnosis of viral illnesses in children is promising.

\section{Disclosure}

The authors declare no conflicts of interest in this work.

\section{References}

1. Tregoning JS, Schwarze J. Respiratory viral infections in infants: causes, clinical symptoms, virology, and immunology. Clin Microbiol Rev. 2010;23(1):74-98.

2. Regamey N, Kaiser L, Roiha HL, et al; Paediatric Respiratory Research Group. Viral etiology of acute respiratory infections with cough in infancy: a community-based birth cohort study. Pediatr Infect Dis J. 2008;27(2):100-105.

3. Greenberg SB. Respiratory viral infections in adults. Curr Opin Pulm Med. 2002;8(3):201-208.

4. Sloots TP, Whiley DM, Lambert SB, Nissen MD. Emerging respiratory agents: new viruses for old diseases? J Clin Virol. 2008;42(3): 233-243.

5. Van der Zalm MM, van Ewijk BE, Wilbrink B, Uiterwaal CS, Wolfs TF, van der Ent CK. Respiratory pathogens in children with and without respiratory symptoms. J Pediatr. 2009;154(3):396-400,400.e1.

6. Rawlinson WD, Waliuzzaman Z, Carter IW, Belessis YC, Gilbert KM, Morton JR. Asthma exacerbations in children associated with rhinovirus but not human metapneumovirus infection. J Infect Dis. 2003; 187(8):1314-1318.

7. Beadling C, Slifka MK. How do viral infections predispose patients to bacterial infections? Curr Opin Infect Dis. 2004;17(3):185-191.

8. Vareille M, Kieninger E, Edwards MR, Regamey N. The airway epithelium: soldier in the fight against respiratory viruses. Clin Microbiol Rev. 2011;24(1):210-229.

9. Walzl G, Tafuro S, Moss P, Openshaw PJ, Hussell T. Influenza virus lung infection protects from respiratory syncytial virus-induced immunopathology. J Exp Med. 2000;192(9):1317-1326.

10. Ralston S, Hill V, Waters A. Occult serious bacterial infection in infants younger than 60 to 90 days with bronchiolitis: a systematic review. Arch Pediatr Adolesc Med. 2011;165(10):951-956.

11. Lehtinen P, Jartti T, Virkki R, et al. Bacterial coinfections in children with viral wheezing. Eur J Clin Microbiol Infect Dis. 2006; 25(7):463-469.

12. Vesa S, Kleemola M, Blomqvist S, Takala A, Kilpi T, Hovi T. Epidemiology of documented viral respiratory infections and acute otitis media in a cohort of children followed from two to twenty-four months of age. Pediatr Infect Dis J. 2001;20(6):574-581.

13. Bulut Y, Guven M, Otlu B, et al. Acute otitis media and respiratory viruses. Eur J Pediatr. 2007;166:223-228.

14. Yano H, Okitsu N, Hori T, et al. Detection of respiratory viruses in nasopharyngeal secretions and middle ear fluid from children with acute otitis media. Acta Otolaryngol. 2008;129:1-6.

15. Mallia P, Johnston SL. Influenza infection and COPD. Int J Chron Obstruct Pulmon Dis. 2007;2(1):55-64.

16. Voynow JA, Rubin BK. Mucins, mucus, and sputum. Chest. 2009;135(2): $505-512$.

17. Thornton DJ, Rousseau K, McGuckin MA. Structure and function of the polymeric mucins in airways mucus. Annu Rev Physiol. 2008; 70:459-486.

18. Rose MC, Voynow JA. Respiratory tract mucin genes and mucin glycoproteins in health and disease. Physiol Rev. 2006;86(1):245-278.

19. Voynow JA, Gendler SJ, Rose MC. Regulation of mucin genes in chronic inflammatory airway diseases. Am J Respir Cell Mol Biol. 2006; 34(6):661-665.

20. Rose MC, Nickola TJ, Voynow JA. Airway mucus obstruction: mucin glycoproteins, MUC gene regulation and goblet cell hyperplasia. Am J Respir Cell Mol Biol. 2001;25(5):533-537.

21. Akira S. Pathogen recognition by innate immunity and its signaling. Proc Jpn Acad Ser B Phys Biol Sci. 2009;85(4):143-156.

22. Akira $S$, Uematsu $S$, Takeuchi O. Pathogen recognition and innate immunity. Cell. 2006;124:783-801.

23. Kanneganti TD, Lamkanfi M, Nunez G. Intracellular NOD-like receptors in host defense and disease. Immunity. 2007;27:549-559.

24. Hansson GK, Edfeldt K. Toll to be paid at the gateway to the vessel wall. Arterioscler Thromb Vasc Biol. 2005;25(6):1085-1087. 
25. Didierlaurent A, Goulding J, Patel S, et al. Sustained desensitization to bacterial Toll-like receptor ligands after resolution of respiratory influenza infection. J Exp Med. 2008;205(2):323-329.

26. Ting JP, Davis BK. CATERPILLER: a novel gene family important in immunity, cell death, and diseases. Annu Rev Immunol. 2005; 23:387-414

27. Chamaillard M, Hashimoto M, Horie Y, et al. An essential role for NOD1 in host recognition of bacterial peptidoglycan containing diaminopimelic acid. Nat Immunol. 2003;4:702-707.

28. Girardin SE, Boneca IG, Carneiro LA, et al. Nod1 detects a unique muropeptide from gram-negative bacterial peptidoglycan. Science. 2003;300:1584-1587.

29. Girardin SE, Boneca IG, Viala J, et al. Nod2 is a general sensor of peptidoglycan through muramyl dipeptide (MDP) detection. J Biol Chem. 2003;278:8869-8872.

30. Inohara N, Ogura Y, Fontalba A, et al. Host recognition of bacterial muramyl dipeptide mediated through NOD2. Implications for Crohn's disease. J Biol Chem. 2003;278:5509-5512.

31. Basler CF, García-Sastre A. Viruses and the type I interferon antiviral system: induction and evasion. Int Rev Immunol. 2002;21(4-5):305-337.

32. Katze MG, He Y, Gale M Jr. Viruses and interferon: a fight for supremacy. Nat Rev Immunol. 2002;2(9):675-687.

33. Message SD, Johnston SL. Host defense function of the airway epithelium in health and disease: clinical background. J Leukoc Biol. 2004;75(1):5-17.

34. Ishizuka S, Yamaya M, Suzuki T, et al. Effects of rhinovirus infection on the adherence of Streptococcus pneumoniae to cultured human airway epithelial cells. J Infect Dis. 2003;188(12):1928-1939.

35. Pittet LA, Hall-Stoodley L, Rutkowski MR, Harmsen AG. Influenza virus infection decrease stracheal mucociliary velocity and clearance of Streptococcus pneumoniae. Am J Respir Cell Mol Biol. 2010;42(4):450-460.

36. Wilson R, Dowling RB, Jackson AD. The biology of bacterialcolonization and invasion of the respiratory mucosa. Eur Respir J. 1996;9(7):1523-1530

37. Tristram DA, Hicks W Jr, Hard R. Respiratory syncytial virus and human bronchial epithelium. Arch Otolaryngol Head Neck Surg. 1998; 124:777-783

38. McCullers JA, Iverson AR, McKeon R, Murray PJ. The platelet activating factor receptor is not required for exacerbation of bacterial pneumonia following influenza. Scand J Infect Dis. 2008;40(1):11-17.

39. Bragonzi A, Copreni E, de Bentzmann S, Ulrich M, Conese M. Airway epithelial cell-pathogen interactions. J Cyst Fibros. 2004; 3(suppl 2):197-201.

40. Avadhanula V, Wang Y, Portner A, Adderson E. Non typeable Haemophilus influenzae and Streptococcus pneumoniae bind respiratory syncytial virus glycoprotein. J Med Microbiol. 2007;56:1133-1137.

41. Fukasawa C, Ishiwada N, Ogita J, Hishiki H, Kohno Y. The effects of disodium cromoglycate on enhanced adherence of Haemophilus influenzae to A549 cells infected with respiratory syncytial virus. Pediatr Res. 2009;66:168-173.

42. Hament JM, Aerts PC, Fleer A, et al. Direct binding of respiratory syncytial virus to pneumococci: a phenomenon that enhances both pneumococcal adherence to human epithelial cells and pneumococcal invasiveness in a murine model. Pediatr Res. 2005;58:1198-1203.

43. Van Ewijk BE, Wolfs TF, Aerts PC, et al. RSV mediates Pseudomonas aeruginosa binding to cystic fibrosis and normal epithelial cells. Pediatr Res. 2007;61:398-403.

44. Wang JH, Kwon HJ, Jang YJ. Rhinovirus enhances various bacterial adhesions to nasal epithelial cells simultaneously. Laryngoscope. 2009;119:1406-1411.

45. Avadhanula V, Rodriguez CA, Devincenzo JP, et al. Respiratory viruses augment the adhesion of bacterial pathogens to respiratory epithelium in a viral species- and cell type-dependent manner. J Virol. 2006;80(4):1629-1636.

46. McCullers JA, Rehg JE. Lethal synergism between influenza virus and Streptococcus pneumoniae: characterization of a mouse model and the role of platelet-activating factor receptor. J Infect Dis. 2002;186(3):341-350.
47. Hassett DJ, Korfhagen TR, Irvin RT, et al. Pseudomonas aeruginosa biofilm infections in cystic fibrosis: insights into pathogenic processes and treatment strategies. Expert Opin Ther Targets. 2010;14:117-130.

48. Morris DP. Bacterial biofilm in upper respiratory tract infections. Curr Infect Dis Rep. 2007;9:186-192.

49. Saadi AT, Blackwell CC, Essery SD, et al. Developmental and environmental factors that enhance binding of Bordetella pertussis to human epithelial cells in relation to sudden infant death syndrome (SIDS). FEMS Immunol Med Microbiol. 1996;16:51-59.

50. Saadi AT, Blackwell CC, Raza MW, et al. Factors enhancing adherence of toxigenic Staphylococcus aureus to epithelial cells and their possible role in sudden infant death syndrome. Epidemiol Infect. 1993;110:507-517.

51. Cook DN, Pisetsky DS, Schwartz DA. Toll-like receptors in the pathogenesis of human disease. Nat Immunol. 2004;5:975-979.

52. Nansen A, Randrup Thomsen A. Viral infection causes rapid sensitization to lipopolysaccharide: central role of IFN-alpha beta. J Immunol. 2001;166:982-988.

53. Doughty L, Nguyen K, Durbin J, Biron C. A role for IFN-alpha beta in virus infection-induced sensitization to endotoxin. J Immunol. 2001; 166:2658-2664.

54. Passariello C, Schippa S, Conti C, et al. Rhinoviruses promote internalisation of Staphylococcus aureus into non-fully permissive cultured pneumocytes. Microbes Infect. 2006;8:758-766.

55. Kim YG, Park JH, Reimer T, et al. Viral infection augments Nod1/2 signaling to potentiate lethality. Cell Host Microbe. 2011; $9(6): 496-507$

56. O’Brien KL, Walters MI, Sellman J, et al. Severe pneumococcal pneumonia in previously healthy children: the role of preceding influenza infection. Clin Infect Dis. 2000;30:784-789.

57. Nascimento-Carvalho CM, Ribeiro CT, Cardoso MR, et al. The role of respiratory viral infections among children hospitalized for communityacquired pneumonia in a developing country. Pediatr Infect Dis $J$. 2008;27(10):939-941.

58. Juvén T, Mertsola J, Waris M, et al. Etiology of community-acquired pneumonia in 254 hospitalized children. Pediatr Infect Dis J. 2000; 19(4):293-298.

59. Pons-Catalano C, Vallet C, Lorrot M, et al. Community acquired pneumonia and influenza in children. Arch Pediatr. 2003;10(12): 1056-1060.

60. Syrjanen RK, Kilpi TM, Kaijalainen TH, Herva EE, Takala AK. Nasopharyngeal carriage of Streptococcus pneumoniae in Finnish children younger than 2 years old. J Infect Dis. 2001;184:451-459.

61. Henderson FW, Collier AM, Sanyal MA, et al. A longitudinal study of respiratory viruses and bacteria in the etiology of acute otitis media with effusion. $N$ Engl J Med. 1982;306:1377-1383

62. Peltola VT, McCullers JA. Respiratory viruses predisposing to bacterial infections: role of neuraminidase. Pediatr Infect Dis J. 2004;23 (1 suppl):S87-S97.

63. Ruuskanen O, Arola M, Putto-Laurila A, Mertsola J, Meurman O, Viljanen MK. Acute otitis media and respiratory virus infections. Pediatr Infect Dis J. 1989;8:94-99.

64. Koivunen P, Kontiokari T, Niemela M, Pokka T, Uhari M. Time to development of acute otitis media during an upper respiratory tract infection in children. Pediatr Infect Dis J. 1999;18:303-305.

65. Heikkinen T. Temporal development of acute otitis media during upper respiratory tract infection. Pediatr Infect Dis J. 1994;13:659-661.

66. Gwaltney JM. Sinusitis. In: Mandell GL, Bennett JE, Dolin R, editors. Mandell, Douglas and Bennett's Principles and Practices of Infectious Diseases. 4th ed. New York: Churchill Livingstone; 1995:585-590.

67. Purcell K, Fergie J. Concurrent serious bacterial infections in 2396 infants and children hospitalized with respiratory syncytial virus lower respiratory tract infections. Arch Pediatr Adolesc Med. 2002;156(4):322-324.

68. Greenes DS, Harper MB. Low risk of bacteremia in febrile children with recognizable viral syndromes. Pediatr Infect Dis J. 1999;18:258-261 
69. Bilavsky E, Shouval DS, Yarden-Bilavsky H, Fisch N, Ashkenazi S, Amir J. A prospective study of the risk for serious bacterial infections in hospitalized febrile infants with or without bronchiolitis. Pediatr Infect Dis J. 2008;27(3):269-270.

70. Luginbuhl LM, Newman TB, Pantell RH, Finch SA, Wasserman RC. Office-based treatment and outcomes for febrile infants with clinically diagnosed bronchiolitis. Pediatrics. 2008;122(5):947-954.

71. Liebelt EL, Qi K, Harvey K. Diagnostic testing for serious bacterial infections in infants aged 90 days or younger with bronchiolitis. Arch Pediatr Adolesc Med. 1999;153(5):525-530.

72. Antonow JA, Hansen K, McKinstry CA, Byington CL. Sepsis evaluations in hospitalized infants with bronchiolitis. Pediatr Infect Dis J. 1998;17(3):231-236.

73. Levine DA, Platt SL, Dayan PS, et al. Multicenter RSV-SBI Study Group of the Pediatric Emergency Medicine Collaborative Research Committee of the American Academy of Pediatrics. Risk of serious bacterial infection in young febrile infants with respiratory syncytial virus infections. Pediatrics. 2004;113(6):1728-1734.

74. Oray-Schrom P, Phoenix C, St Martin D, Amoateng-Adjepong Y. Sepsis workup in febrile infants 0-90 days of age with respiratory syncytial virus infection. Pediatr Emerg Care. 2003;19(5):314-319.

75. Kuppermann N, Bank DE, Walton EA, Senac MO Jr, McCaslin I. Risks for bacteremia and urinary tract infections in young febrile children with bronchiolitis. Arch Pediatr Adolesc Med. 1997;151(12):1207-1214.

76. Hendaus MA, Alhammadi AH, Khalifa MS, Muneer E, Chandra P. Risk of urinary tract infection in infants and children with acute bronchiolitis. Paediatr Child Health. 2015;20(5):e25-e29.

77. Rittichier KR, Bryan PA, Bassett KE, et al. Diagnosis and outcomes of enterovirus infections in young infants. Pediatr Infect Dis J. 2005; 24(6):546-550.

78. Haller O, Kochs G. Human MxA protein: an interferon-induced dynamin-like GTPase with broad antiviral activity. J Interferon Cytokine Res. 2011;31(1):79-87.

79. Engelmann I, Dubos F, Lobert PE, et al. Diagnosis of viral infections using myxovirus resistance protein A (MxA). Pediatrics. 2015;135(4):e985-e993.

80. Nakabayashi M, Adachi Y, Itazawa T, et al. MxA-based recognition of viral illness in febrile children by a whole blood assay. Pediatr Res. 2006;60(6):770-774.

81. Kawamura M, Kusano A, Furuya A, et al. New sandwich-type enzymelinked immunosorbent assay for human MxA protein in a whole blood using monoclonal antibodies against GTP-binding domain for recognition of viral infection. J Clin Lab Anal. 2012;26(3):174-183.

82. Yoshimasu T, Manabe A, Ebihara Y, et al. MxA expression in patients with viral infection after allogeneic stem cell transplantation. Bone Marrow Transplant. 2003;32(3):313-316.

83. Ghidini C, Zanotti C, Boccacci S, Lanfranchi A, Caimi L, Imberti L. MxA RNA quantification in febrile patients who underwent hematopoietic cell transplantation for primary immunodeficiency. Diagn Mol Pathol. 2011;20(2):111-116.

84. Gravenstein S, Davidson HE. Current strategies for management of influenza in the elderly population. Clin Infect Dis. 2002;35:729-737.

85. McCullers JA, Bartmess KC. Role of neuraminidase in lethal synergism between influenza virus and Streptococcus pneumoniae. J Infect Dis. 2003;187:1000-1009.
86. Heikkinen T, Block SL, Toback SL, Wu X, Ambrose CS. Effectiveness of intranasal live attenuated influenza vaccine against all-cause acute otitis media in children. Pediatr Infect Dis J. 2013;32(6):669-674.

87. Felix F, Gomes GA, Cabral GA, Cordeiro JR, Tomita S. The role of new vaccines in the prevention of otitis media. Braz J Otorhinolaryngol. 2008;74(4):613-616.

88. Russell F, Mulholland K. Prevention of otitis media by vaccination. Drugs. 2002;62(10):1441-1445.

89. Nichol KL, Wuorenma J, von Sternberg T. Benefits of influenza vaccination for low-, intermediate-, and high-risk senior citizens. Arch Intern Med. 1998;158:1769-1776.

90. Marchisio P, Cavagna R, Maspes B, et al. Efficacy of intranasal virosomal influenza vaccine in the prevention of recurrent acute otitis media in children. Clin Infect Dis. 2002;35(2):168-174.

91. Christenson B, Hedlund J, Lundbergh P, Ortqvist A. Additive preventive effect of influenza and pneumococcal vaccines in elderly persons. Eur Respir J. 2004;23(3):363-368.

92. Hedlund J, Christenson B, Lundbergh P, Ortqvist A. Effects of a largescale intervention with influenza and 23 -valent pneumococcal vaccines in elderly people: a 1-year follow-up. Vaccine. 2003;21:3906-3911.

93. Veenhoven R, Bogaert D, Uiterwaal C, Brouwer C, Kiezebrink H, Bruin J. Effect of conjugate pneumococcal vaccine followed by polysaccharide pneumococcal vaccine on recurrent acute otitis media: a randomised study. Lancet. 2003;361(9376):2189-2195.

94. Fortanier AC, Venekamp RP, Boonacker CW, et al. Pneumococcal conjugate vaccines for preventing otitis media. Cochrane Database Syst Rev. 2014;4:CD001480.

95. Jackson LA, Neuzil KM, Yu O, et al; Vaccine Safety Datalink. Effectiveness of pneumococcal polysaccharide vaccine in older adults. N Engl J Med. 2003;348:1747-1755.

96. McNicholl IR, McNicholl JJ. Neuraminidase inhibitors: zanamivir and oseltamivir. Ann Pharmacother. 2001;35(1):57-70.

97. Wang K, Shun-Shin M, Gill P, Perera R, Harnden A. Neuraminidase inhibitors for preventing and treating influenza in children (published trials only). Cochrane Database Syst Rev. 2012;4:CD002744.

98. Whitley RJ, Hayden FG, Reisinger KS, et al. Oral oseltamivir treatment of influenza in children. Pediatr Infect Dis J. 2001;20:127-133.

99. Muthuri SG, Myles PR, Venkatesan S, Leonardi-Bee J, Nguyen-VanTam JS. Impact of neuraminidase inhibitor treatment on outcomes of public health importance during the 2009-2010 influenza A(H1N1) pandemic: a systematic review and meta-analysis in hospitalized patients. J Infect Dis. 2013;207(4):553-563.

100. Kaiser L, Wat C, Mills T, Mahoney P, Ward P, Hayden F. Impact of oseltamivir treatment on influenza-related lower respiratory tract complications and hospitalizations. Arch Intern Med. 2003;163: 1667-1672

101. Treanor JJ, Hayden FG, Vrooman PS, et al. Efficacy and safety of the oral neuraminidase inhibitor oseltamivir in treating acute influenza: a randomized controlled trial: US Oral Neuraminidase Study Group JAMA. 2000;283:1016-1024.

102. Carbonell-Estrany X, Simões EA, Dagan R, et al. Motavizumab for prophylaxis of respiratory syncytial virus in high-risk children: a noninferiority trial. Pediatrics. 2010;125(1):e35-e51.
Therapeutics and Clinical Risk Management

\section{Publish your work in this journal}

Therapeutics and Clinical Risk Management is an international, peerreviewed journal of clinical therapeutics and risk management, focusing on concise rapid reporting of clinical studies in all therapeutic areas, outcomes, safety, and programs for the effective, safe, and sustained use of medicines. This journal is indexed on PubMed Central, CAS,

\section{Dovepress}

EMBase, Scopus and the Elsevier Bibliographic databases. The manuscript management system is completely online and includes a very quick and fair peer-review system, which is all easy to use. Visit http://www.dovepress.com/testimonials.php to read real quotes from published authors. 